\title{
AJARAN SUNAN GESENG BAGI KEHIDUPAN KEAGAMAAN MASYARAKAT
}

\section{Dina Faelasofa}

Institut Ilmu Qur'an Wonosobo, Jawa Tengah Indonesia

\section{Info Artikel}

Sejarah Artikel:

Diterima Juni 2011

Disetujui Juli 2011

Dipublikasikan September

2011

Keywords:

religiousity;

ritual;

sunan geseng tought;

society.

\begin{abstract}
Abstrak
Tujuan penelitian ini adalah untuk menggambarkan pengaruh ajaran Sunan Geseng bagi kehidupan keagamaan masyarakat di wilayah Grabag Magelang. Sunan Geseng adalah seorang tokoh agama atau disebut wali yang menyebarkan agama Islam di wilayah Grabag, Kabupaten Magelang yang sampai sekarang ajaran-ajarannya masih dilaksanakan oleh masyarakat di wilayah Grabag, yang diwujudkan dalam kehidupan keagamaan yang dilakukan oleh masyarakat di wilayah komplek makam Sunan Geseng. Penelitian ini merupakan penelitian kualitatif dengan mengadopsi pola studi kasus. Data dikumpulkan dengan metode wawancara dan observasi. Hasil penelitian mengungkapkan beberapa fakta tentang kuatnya pengaruh ajaran Sunan Geseng terhadap kehidupan masyarakat Grabag Magelang. Contohnya, makam Sunan Geseng yang digunakan sebagai tempat wisata spiritual keagamaan, yang banyak dikunjungi para peziarah. Selain itu ada tradisi selikuran yang dilaksanakan setahun sekali pada malam ke-21 bulan Ramadhan di kompleks makam Sunan Geseng. Juga masih terdapat kegiatan keagamaan masyarakat yang menganut ajaran Sunan Geseng seperti tradisi slametan, gendurenan, methoan, dan tradisi-tradisi yang lainnya. Hal lain yang menarik adalah banyak pondok pesantren yang sistem pengelolaan maupun pengajarannya serupa dengan pondok pesantren rintisan Sunan Geseng. Hal ini membuktikan teori sentimen kemasyarakatan yang menyatakan bahwa peristiwa sejarah masa lampau dan peninggalan-peninggalan Sunan Geseng menjadi dasar sentimen kemasyarakatan.
\end{abstract}

\begin{abstract}
The objective of this research is to describe the influence of Sunan Geseng religious teachings on the society of Grabag, Magelang. Sunan Geseng is a religious figure or called wali who spreaded Islam in Grabag region, Magelang. His religious teachings are still implemented and hold by the society in Grabag region, living in Sunan Geseng cemetary area. The method used in this study is a qualitative research which also adopted the pattern of case study. Data was collected through interview and observation. Research results show the strong influence of Sunan Geseng's religious teaching is apparent in Grabag, Magelang. Among the indicators are the use of Sunan Geseng's cemetery as spiritual tourism site visited by people from many area. There is also selikuran tradition held annually at the 21st night of Ramadhan in Sunan Geseng cemetery area. There are also other rituals like slametan, gendurenan, and methoan. Another interesting thing is that many boarding schools still adopt the management system or learning process like those of Sunan Geseng. All of this enforce the society sentiment theory stating that historical memory in the the past and Sunan Geseng heritages are fondation for society sentiment.
\end{abstract}

(C) 2011 Universitas Negeri Semarang 


\section{PENDAHULUAN}

Sebagaimana diketahui bahwa masyarakat di Kecamatan Grabag merupakan masyarakat yang berintikan adat istiadat yang pada dasarnya menjadi pedoman hidup yang kuat bagi penduduk yang menghayatinya. Nilai-nilai budaya yang dianggap luhur oleh masyarakat pendukungnya cenderung akan diwariskan dari satu generasi kepada generasi berikutnya secara lisan dan dengan perbuatan yang sesuai dengan nilai-nilai budaya tersebut. Masyarakat Jawa dengan budayanya sangat lekat sekali dengan kepercayaan yang penuh dengan mitologisasi (memitoskan), sakralisasi (mengkeramatkan), dan mistifikasi (memandang sesuatu sebagai misteri). Kesemuanya itu merupakan mitologi yang dapat ditemukan pada orang, tempat, waktu dan peristiwa. Hal terlihat dalam nama, kelahiran, waktu, huruf, angka dan keberuntungan. Realitas mitos Jawa tersebut termanifestasi melalui bentuk upacara ritual (Fitri, 2008).

Seperti halnya agama Islam yang juga erat hubungannya dengan sesuatu yang dianggap sakral, yaitu yang mempunyai nilai dan makna istimewa dan menimbulkan rasa hormat. Agama sebagai salah satu unsur dari kebudayaan yang diwariskan secara turun temurun baik melalui sosialisasi maupun enkulturasi. Selain itu solidaritas yang terjalin antar warga sangat tinggi yang mangakibatkan adanya rasa saling memerlukan dan berbagai kebiasaan masyarakat, perilaku-perilaku tertentu yang secara khas merupakan ciri masyarakat. Seperti halnya sebagian besar penduduk pedesaan lereng Merapi, penduduk Tutup Ngisorpun memiliki kepercayaan agama terbesar yaitu Islam, meskipun dalam kesehariannya, ternyata tidak semua umat Islam menjalankan secara penuh kewajibannya, baik sholat maupun puasa. Mereka masih melakukan ritual yang berbau animism dan dinamisme seperti memberikan sesajen dan penghormatan pada leluhur secara berlebihan (Budiyanto, et all, 2008).

Suparlan (dalam Robertson, 1992: 5-6) menjelaskan agama secara mendasar dan umum dapat didefinisikan sebagai se- perangkat aturan dan peraturan yang mengatur hubungan manusia dengan manusia lainnya dan mengatur hubungan manusia dengan lingkungannya yang manifestasinya dapat dilihat dalam bentuk kaidah-kaidah, ritus-ritus, doa-doa dan lain sebagainya. Bahkan orang dapat menyaksikan sejumlah ungkapan lain yang sangat menarik, seperti lambang-lambang keagamaan, pola-pola kelakuan tertentu, cara bermisi (dakwah) dan lain sebagainya. Ada tiga model kategori; kepercayaan yang berbasis pada pola tradisional Islam, kepercayaan mistis yang berbasis pada tradisi, dan kepercayaan yang berdasar pada pemikiran-rasional belaka. Berbagai ragam kepercayaan ini menunjukkan bahwa kita tidak bisa membuat klaim-klaim sepihak kepada para peziarah makam (Aziz, Amir . et all, 2004).

Agama Islam diturunkan demi kepentingan umat manusia melalui Nabi Muhammad SAW. Agama Islam tidak hanya bertujuan memperkenalkan eksistensinya sebagai agama, tetapi juga mengakui eksistensi agama-agama lain, serta menumbuhkan kesadaran untuk menerima ajaran-ajaran spiritual yang luhur, dan melaksanakannya dalam praktek (Iberani dan Hidayat, 2003: 70).

Mempertahankan kearifan dan kepercayaan local merupakan suatu upaya untuk meningkatkan kebijaksanaan dalam berperilaku dalam masyarakat, termasuk di dalamnya terkait dengan nilai, norma, aturan maupun adat istiadat suatu bangsa (Sartini, 2004). Salah satu kepercayaan local Islam ada di wilayah Grabag terkenal seorang tokoh agama yang berperan dalam penyebaran agama Islam di wilayah tersebut. Tokoh itu adalah Sunan Geseng. Sunan Geseng merupakan salah satu dari beberapa wali yang diakui hanya di daerah setempat ia tinggal. Menurut cerita rakyat setempat, serta yang ditulis oleh Danandjaya (1986: 69) Sunan Geseng adalah Haji Abdurrahman. Sunan Geseng berasal dari Desa Krendetan (Bagelan, atau sekarang disebut Kedu) di Jawa Tengah. Sunan Geseng adalah putra Kyai Kuat dan murid Sunan Kali Jaga. Sunan Geseng telah mendapat julukan "Geseng", yang berarti hangus karena terbakar seluruh tubuhnya didalam suatu kebakaran hutan, 
tetapi secara mukjizat dapat selamat. Sunan Geseng melaksanakan dakwah di kawasan sekitar Magelang dan mendirikan padepokan di Kalialang (sekarang Kleteran) Kecamatan Grabag. Oleh sebab itu maka makam Sunan Geseng ada di desa Tirto, Kecamatan Grabag.

Dalam agama Islam memiliki cara tersendiri yang ditempuh untuk mendekatkan diri dengan Tuhan, cara tersebut adalah memahami ajaran-ajaran agama Islam. Masyarakat beranggapan dengan memahami ajaran Tuhan maka mereka akan memahami kemauan Tuhan. Manusia berharap dengan mempelajari ajaran Tuhan maka manusia akan terhindar dari kesalahan di dunia maupun di akherat. Proses untuk memahami Tuhan ini dapat dilaksanakan dengan cara pengkajian terhadap ajaran atau wahyu Tuhan yang dibawa oleh utusannya yaitu nabi. Pengkajian ini dapat berupa ceramah/ khotbah agama yang diberikan oleh pemuka agama, selain penelaahan bersama terhadap ajaran atau wahyu Tuhan tersebut ceramah atau khotbah ini dilakukan secara bersamasama dengan seorang pemuka agama sebagai sumbernya. Geertz (1981: 477) menambahkan bahwa kegiatan-kegiatan keagamaan tidak hanya merupakan tindakan-tindakan yang bersifat pemujaan, tetapi juga semua perilaku yang ada kaitanya dengan wujudwujud yang dipuja oleh manusia itu sendiri.

Masyarakat di wilayah Grabag yang sebagian besar beragama Islam, dalam melakukan aktivitas keagamaan cenderung memperhatikan kebiasaan-kebiasaan yang berlaku atau adat setempat. Hal tersebut dikarenakan pengaruh Islam NU telah mendominasi keberagamaan yang berkembang di dalam masyarakat yang mayoritas masyarakatnya bermahzab syafi'iyah. Dimana NU telah mengembangkannya melalui kultur masyarakat pedesaan yang ajaran-ajarannya dianggap bisa menerima adat-istiadat yang dikembangkan oleh masyarakat.

Peranan ajaran Sunan Geseng dalam kehidupan keagamaan masyarakat di wilayah Grabag juga dikuatkan dengan banyaknya peziarah yang datang ke makam Sunan Geseng di desa Tirto, Kecamatan Grabag, Kabupaten Magelang. Pada umumnya me- reka berziarah pada hari-hari tertentu seperti malam Jum'at Kliwon, meskipun pada harihari biasa pun juga banyak peziarah yang datang, jumlah peziarah terbanyak yaitu pada malam tradisi selikuran. Nilai-nilai Islam yang diajarkan oleh Sunan Geseng kemudian diserap menjadi bagian dari budaya Jawa yang dikenal dengan Jawanisasi Islam yaitu upaya menginternalisasikan nilai-nilai Jawa melalui cara penyusupan kedalam budaya Islam. Hal tersebut masih dapat dilihat dengan adanya upacara haul yang dilakukan oleh masyarakat setempat. Selain hal tersebut masyarakat di wilayah Grabag juga menganut aliran ahlussunah wal jama'ah yaitu aliran yang melaksanakan ajaran-ajaran sunah nabi yang dipercaya oleh masyarakat merupakan ajaran Sunan Geseng. Selain itu juga banyak pondok pesantren yang sistem pengelolaan maupun pengajarannya serupa dengan pondok rintisan pengikut Sunan Geseng, bahkan ada yang langsung merujuk dengan menggunakan nama Pondok Pesantren Sunan Geseng. Mengapa ajaran Sunan Geseng sampai sekarang ini masih berperan bagi kehidupan keagamaan masyarakat di wilayah Grabag, kabupaten Magelang dan bagaimana kegiatan keagamaan yang dilakukan oleh masyarakat di wilayah Kecamatan Grabag yang didasarkan oleh ajaran Sunan Geseng.

\section{METODE PENELITIAN}

Pendekatan penelitian yang dipilih adalah pendekatan kualitatif, yaitu pendekatan dengan cara melihat objek kajian sebagai satuan yang terdiri dari unsur yang saling terkait. Penelitian kualitatif mengutamakan kualitas data, oleh karena itu tehnik pengumpulan datanya banyak menggunakan wawancara yang berkesinambungan dan observasi langsung. Penelitian ini menggunakan metode kualitatif, karena secara langsung dapat menyajikan hakekat hubungan antara peneliti dan responden lebih peka. Bodgan dan Taylor (dalam Moleong, 2002: 2) menjelaskan metode kualitatif adalah sebagai prosedur penelitian yang menghasilkan data deskriptif yang berupa kata-kata tertulis atau lisan dari orang-orang dan perilaku yang diamati. 
Penelitian bertujuan menggambarkan atau menguraikan tentang kehidupan keagamaan masyarakat di wilayah Grabag yang masih percaya dan menjalankan ajaran Sunan Geseng. Dalam penelitian ini menghasilkan data deskriptif analisis yang berupa kata-kata tertulis terhadap apa yang diamati, atau dengan kata lain data yang dianalisis dan hasil analisisnya itu berbentuk deskriptif. Selain pendekatan kualitatif murni dalam penelitian ini digunakan metode penelitian lapangan berupa studi kasus, yaitu pendekatan suatu kasus ke dalam konteksnya secara normal tanpa adanya intervensi pihak luar. Dalam penelitian ini studi kasus digunakan untuk memperoleh informasi tentang kegiatan-kegiatan keagamaan masyarakat di wilayah Grabag yang masih mempercayai dan menjalankan ajaran-ajaran Sunan Geseng.

Lokasi sekitar komplek makam dan pondok pesantren Sunan Geseng di wilayah Kecamatan Grabag, Kabupaten Magelang, yaitu antara lain di Desa Tirto, Tlogorejo, dan Kleteran. Alasan peneliti memilih judul Ajaran Sunan Geseng bagi Kehidupan Keagamaan Masyarakat di Wilayah Grabag adalah untuk mengetahui latar belakang masih dilaksanakannya ajaran Sunan Geseng dalam kehidupan keagamaan masyarakat di wilayah Grabag dan kegiatan-kegiatan keagamaan yang dilakukan oleh masyarakat di wilayah Grabag. Objek dalam penelitian ini adalah masyarakat yang berada di tiga desa di sekitar komplek makam Sunan Geseng dan Pondok Pesantren Sunan Geseng yaitu Desa Tirto, Desa Tlogorejo dan Desa Kleteran. Informan pertama dalam penelitian ini adalah para pemuka agama di wilayah Grabag, kabupaten Magelang. Informan kedua yaitu masyarakat sekitar kompleks dan makam Sunan Geseng, serta masyarakat yang ada di wilayah grabag pada umumnya, yang masih menjalankan ajaran Sunan Geseng. Dalam penelitian ini penulis mengambil informan juga mengambil beberapa orang sebagai informan kunci (key informant) yaitu pemimpin Pondok Pesantren Sunan Geseng dan juru kunci Makam Sunan Geseng yang dianggap lebih mengetahui sejarah penyebaran agama Islam yang dilakukan oleh Sunan Geseng. Pengumpulan data dan tek- nik pengumpulan data yang tepat memungkinkan diperoleh data yang objektif (Moleong, 2002: 105). Teknik pengumpulan data yang digunakan dalam penelitian ini dengan menggunakan wawancara, observasi (pengamatan) dan dokumentasi.

\section{HASIL DAN PEMBAHASAN}

Sunan atau yang disebut wali, sebagai penyebar agama Islam tentunya memiliki pengetahuan tentang agama Islam yang luas. Sunan juga memilki pengetahuan tentang ilmu mukjizat (artinya ajaib atau dapat menimbulkan keheranan). Juga memiliki karomah yaitu perkara yang luar biasa bersamaan dengan pengakuan kewaliannya. Pengetahuan tentang agama Islam ataupun pengetahuan tentang ilmu mukjizat yang dimiliki para wali atau sunan masing-masing berbeda. Sunan Giri misalnya, Sunan Giri dikabarkan memilki paweruh sadurunge winaroh atau mengetahui gejala-gejala zaman yang akan datang. Dalam menyebarkan agama caranya pun berbeda-beda ada yang menggunakan wayang sebagai sarana, ada juga yang menggunakan perumpamaan hidup, bahkan tembang pun dijadikan sarana untuk menyampaikan syiar Islam. Pada umumnya dalam menyampaikan syiar Islam sunan menggunakan bahasa sederhana, mudah dicerna sesuai dengan tingkat kecerdasan masyarakat yang sedang diajak mencari jalan Allah (Arroisi, 2000: 18). Sunan Geseng yang masa mudanya bernama Cokrojoyo, putra Tumenggung Wonojoyo. Dengan mewarisi kedudukan ayahnya, Cokrojoyo diangkat sebagai Tumenggung yang diberi kuasa memerintah wilayah Bagelen, Purworejo, dibawah kedaulatan Kerajaan Majapahit. Kelebihannya sebagai penguasa, Cokrojoyo tidak bersikap gung binathara, yaitu sikap seolah-olah Cokrojoyo adalah satu-satunya orang yang berkuasa. Cokrojoyo tetap merakyat dan memperhatikan kawula alit atau masyarakat kecil. Cokrojoyo mengajari masyarakat cara bertani dan mengolah hasil bumi menjadi barang dagangan yang menguntungkan.

Sebagaimana leluhurnya yang turuntemurun memegang pemerintahan Bagelen sejak zaman Mataram Purba, Cokrojoyo 
menganut agama Hindu-Budha. Dalam garis silsilahnya ayahnya, Wonojoyo adalah putra Tumenggung Wirantoko, pelanjut tahta Tumenggung Kertosuro. Berarti, Cokrojoyo mempunyai titisan darah biru Pangeran Semono yang lebih dikenal dengan Pangeran Muryo. Cokrojoyo yang dikisahkan menjadi seorang penderes kelapa saat Islam mulai berkembang di Jawa Tengah. Dikisahkan saat Cokrojoyo menderes air kelapa, selalu menyanyikan salah satu tembang macapat yaitu pucung. Dalam tembang pucung tersebut tersirat sebuah makna nasib malang penderes kelapa. Ketika mengalunkan tembang pucung tersebut didengar oleh Sunan Kalijaga yang sedang mengadakan perjalanan dakwah kearah selatan dan barat wilayah Jawa Tengah. Sunan Kalijaga berniat mengganti tembang pucung tersebut menjadi sebuah tembang indah berlirik kalimah taukhid, sholawat, dan basmalah yang semuanya dalam bahasa Arab dan Jawa.

Pada saat setelah masjid Agung Demak selesai dibuat, Sunan Drajad membekali Sunan Geseng sepotong tatal (serpihan kayu), sisa kayu yang dibuat soko guru. Sunan Drajat berpesan agar tatal itu dibawa pulang melalui Salatiga, dimanapun tatal itu terjatuh, Sunan Geseng harus bermukim disitu, sekaligus membangun pusat dakwahnya. Ternyata tatal itu jatuh di desa Kalialang, Kecamatan Grabag, Kabupaten Magelang, maka padepokan dan masjid Sunan Geseng ada di kawasan itu. Dengan alasan inilah maka penyebaran ajaran agama Islam yang dilakukan oleh Sunan Geseng di pusatkan di wilayah Grabag, selain itu makam dan padepokan Sunan Geseng juga ada di Wilayah Grabag.

Agama (religi) lebih dipandang sebagai wadah lahiriah atau sebagai intisari yang mengatur penyataan iman di forum terbuka (masyarakat) dan yang manifestasinya dapat dilihat (disaksikan) dalam bentuk kaidahkaidah, ritus dan kulkus, doa-doa, dan lain sebagainya. Bahkan manusia dapat menyaksikan sejumlah ungkapan lain yang sangat menarik seperti lambang-lambang keagamaan, pola-pola kelakuan tertentu, cara bermisi (dakwah), rumah-rumah adat, dan sebagainya. Tanpa adanya agama sebagai suatu wadah yang mengatur dan membina maka keseluruhan kebudayaan (religius) tersebut di atas akan sukar dibina dan diwariskan kepada umat beriman berikutnya (Hendropuspito, 1992: 36). Jadi agama sebagai salah satu unsur kebudayaan akan didapatkan dan dipelajari oleh manusia sebagai anggota masyarakat, serta akan diwariskan dari satu generasi ke generasi berikutnya melalui belajar.

Adapun agama dalam pengertian Sosiologi adalah gejala sosial yang umum dan dimiliki oleh seluruh masyarakat yang ada didunia ini, tanpa kecuali. Agama merupakan salah satu aspek dalam kehidupan sosial dan bagian dari sistem sosial suatu masyarakat (Kahmad, 2002: 14). Selain itu agama juga mempunyai fungsi yang sentral dalam kehidupan masyarakat. Fungsi agama bagi manusia dan masyarakatnya antara lain: Fungsi edukatif, Fungsi penyelamatan, Fungsi pengawasan sosial (social control), Fungsi memupuk persaudaraan, Fungsi transformatif

Dalam proses penyebaran agama Islam kepada masyarakat sunan biasanya menggunakan cara-cara yang sederhana, yaitu ada yang menggunakan menggunakan tembang pucung yang liriknya diganti dengan kalimah tauhid, sahadat, dan salawat, yang semuanya dalam bahasa Arab dan Jawa, tetapi banyak pula cara-raca lain yang dilakukan oleh seorang sunan. Berdasarkan uraian di atas, maka model dalam penelitian ini adalah sebagai berikut:

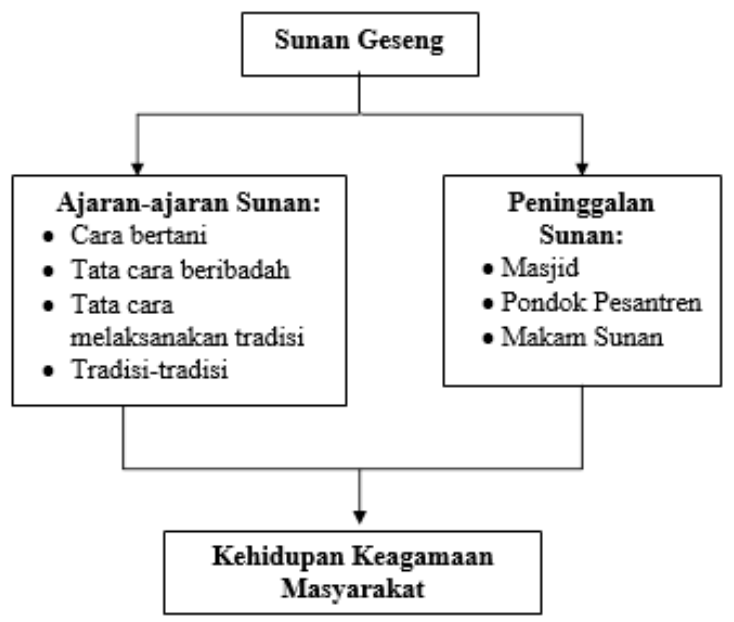

Masyarakat di ke-3 desa yaitu Desa Tirto, Desa Tlogorejo, dan Desa Kleteran 
di wilayah Grabag dalam kehidupan keagamaannya terbagi dalam 3 agama besar yaitu Islam, Katholik, dan Protestan. Tetapi dapat diketahui bahwa jumlah penduduk terbesar adalah beragama Islam. Karena mayoritas penduduk beragama Islam maka untuk menunjang kegiatan keagamaan tersebut banyak terdapat sarana ibadah yang berupa Masjid, Mushola, Langgar atau Surau, maupun Pondok Pesantren yang digunakan sebagai tempat pengajian bapak-bapak pada waktu bulan puasa. Di Desa Kleteran sendiri terdapat 3 Pondok Pesantren, dan di Desa Tirto terdapat sebuah Pondok Pesantren. Karena sebagian besar masyarakat di ke-3 desa tersebut beragama Islam maka tidak ada bangunan tempat ibadah selain tempat ibadah untuk umat Islam. Lembaga formal keagamaan yang ada di wilayah tersebut adalah NU dan Muhammadiyah, tetapi sebagian besar masyarakat mengikuti ajaran Islam NU atau ajaran ahlussunnah waljama'ah.

Karena sebagian besar masyarakat beragama Islam, dalam melaksanakan aktivitas keagamaan pun cenderung memperhatikan kebiasaan-kebiasaan yang berlaku atau adat-istiadat setempat. Hal itu mungkin dikarenakan oleh pengaruh Islam NU dan juga saat ini masyarakat masih memperhatikan dan melestarikan bentuk-bentuk tradisi nenek moyang, meskipun bentuknya bernuansa Islami. Pelaksanaan kegiatan keagamaan ataupun upacara-upacara keagamaan sangat ditentukan oleh kesadaran dari si individu yang mengharuskan untuk mengikuti atau menjalani kegiatan ataupun upacara keagamaan.

Bagi masyarakat tidak semua kegiatan keagamaan dipusatkan di masjid karena ada beberapa upacara keagamaan yang dilaksanakan di rumah warga seperti pelaksanaan upacara syukuran yang syaratnya harus di rumah warga yang memiliki hajat. Syarat ini dimaksudkan agar warga yang bersangkutan mendapatkan berkah dari upacara tasyakuran tersebut. Selain itu rumah kadangkala digunakan untuk pengadaan pengajian oleh kelompok-kelompok tertentu. Biasanya dalam pengajian tersebut masyarakat bersamasama membaca yasin dan tahlil.

Sunan Geseng tumbuh kewaliannya setelah berkenalan dengan Sunan Kalijaga yang diikuti pertobatannya dari ketamakan dunia sehingga Sunan Geseng memutuskan untuk berguru kepada Sunan Kalijaga dan meneruskan perjuangannya dalam syiar Islam di berbagai daerah. Sunan Geseng melaksanakan dakwah di sekitar Magelang. Dan mendirikan padepokan di Kalialang (sekarang Kleteran) Kecamatan Grabag. Oleh sebab cara penyebaran agama Islam yang dilakukan oleh Sunan Geseng menggunakan pendekatan-pendekatan dengan masyarakat kecil baik petani maupun pedagang. Dan penyampaiannya pun menggunakan bahasa yang sederhana yang sesuai dengan daya tangkap masyarakat yang diajak berbicara (Arroisi, 2000:8).

Sunan Geseng yang menyebarkan agama Islam di daerah Magelang, khususnya di wilayah Grabag mendirikan padepokan di Kalialang (sekarang Kleteran), di Desa Kleteran inilah Sunan Geseng mulai berdakwah. Karena masih adanya kepercayaankepercayaan animisme dan dinamisme pada masyarakat, maka dakwah Sunan Geseng sejalan dengan ajaran agama Hindhu dan Budha. Patung-patung peningalan tersebut membuktikan bahwa pada saat kedatangan Sunan Geseng masyarakat di wilayah Grabag dan komplek makam Sunan Geseng masih menganut kepercayaan animisme dan dinamisme. Dalam gambar di bawah ini adalah tempat terdapatnya patung-patung tersebut.

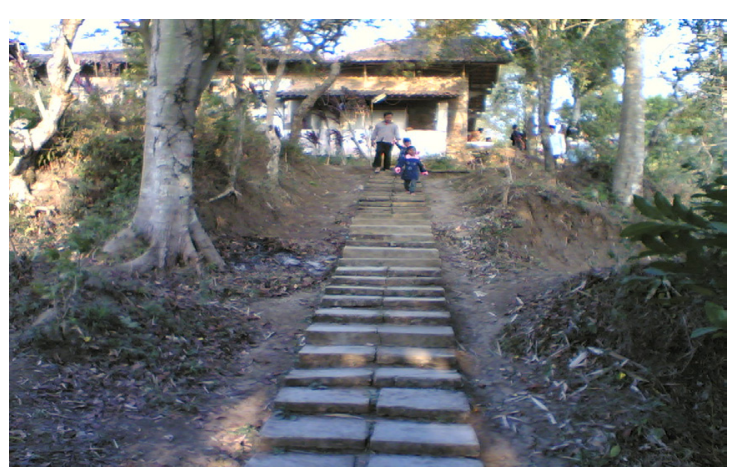

Gambar 1. Lokasi terdapatnya patung-patung sesembahan pada saat Sunan Geseng belum menyebarkan ajaran agama Islam.

Selain hal tersebut di puncak bukit yang sekarang dijadikan makam Sunan Ge- 
seng terdapat batu yang dipercaya bisa mendatangkan berkah.

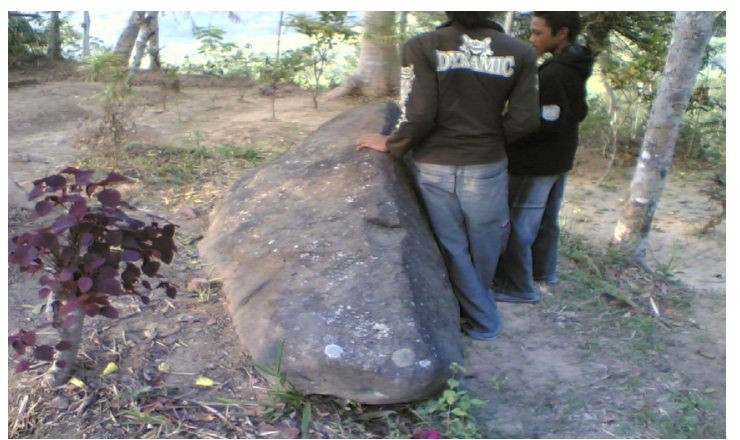

Gambar 2. Batu yang dipercaya oleh masyarakat akan mendatangkan barokah.

Batu yang diceritakan dapat dilihat pada gambar 2, tetapi saat ini ajaran-ajaran yang tidak sesuai dengan ajaran Islam yang diajarkan oleh sunan Geseng tersebut, kemudian diganti dengan kegiatan-kegiatan yang bernuansa Islam, hal ini sesuai dengan ajaran Sunan Geseng yang melarang perbuatan musyrik atau menyekutukan Allah SWT.

Setelah Sunan Geseng meninggal dan dimakamkan di Desa Tirto banyak masyarakat yang berziarah di makam Sunan Geseng tersebut. Tidak hanya warga di sekitar komplek makam Sunan Geseng tetapi peziarah juga banyak yang datang dari berbagai daerah di Kabupaten Magelang dan sekitarnya. Selain itu masyarakat yang datang tidak hanya beragama Islam saja tetapi juga ada warga Tionghoa yang khusus datang untuk meminta berkah agar lancar dalam berdagang, serta banyaknya pengunjung yang sengaja datang ke makam untuk bermalam beberapa hari, berdo'a dan berpuasa. Ada juga peziarah yang berlaku tapa dan menyerahkan diri kepada Allah SWT.

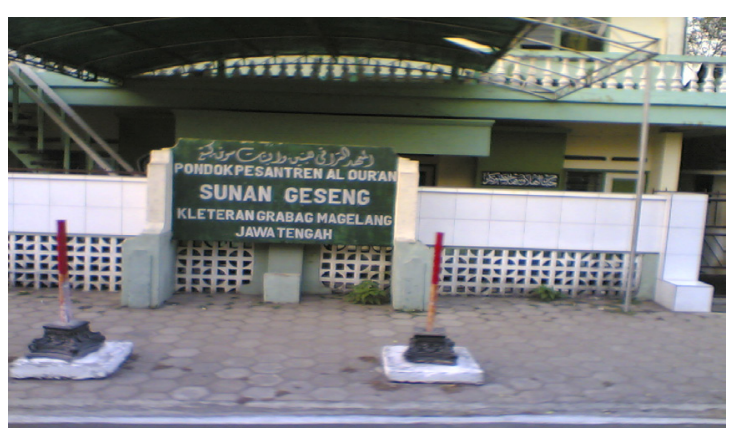

Gambar 3. Pondok Pesantren Sunan Geseng yang didirikan oleh KH. Farham

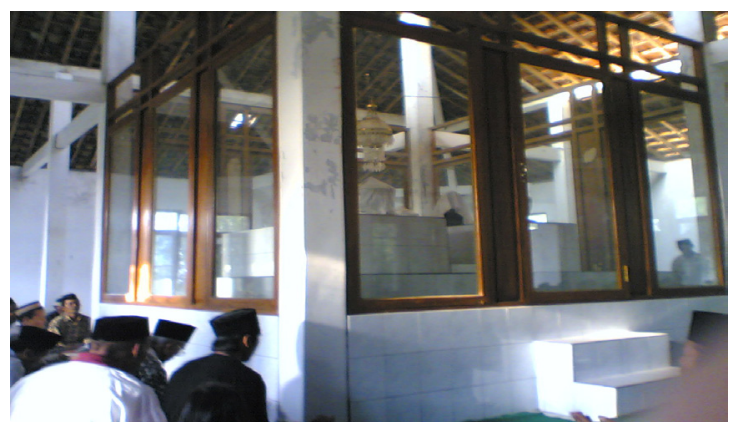

Gambar 4. Makam Sunan Geseng yang terletak di Desa Tirto, Kecamatan Grabag.

Menurut juru kunci makam peziarah yang datang ke makam Sunan Geseng biasanya berombongan, jumlah rombongan pengunjung makam berdasarkan buku tamu tahun 2005-2007 dalam Tabel 1.

Tabel 1. Jumlah Rombongan Pengunjung Makan Berdasar Buku Tamu Tahun 20052007

\begin{tabular}{lc}
\hline \multicolumn{1}{c}{ Nama Kota } & $\begin{array}{c}\text { Jumlah } \\
\text { Rombongan }\end{array}$ \\
\hline Magelang & 112 \\
Semarang & 34 \\
Temanggung & 27 \\
Purworejo & 17 \\
Wonosobo & 15 \\
Kediri dan Sekitarnya & 15 \\
Kendal & 13 \\
Jepara & 10 \\
Kebumen & 6 \\
Kota-kota lain & 5 \\
& 252 \\
\hline
\end{tabular}

Sumber: Buku tamu makam Sunan Geseng tahun 2005-2007

Arroisi (200:15), KH Fathoni yang pada waktu itu merupakan salah seorang tokoh masyarakat yang menjaga makam Sunan Geseng melarang adanya perbuatan musyrik atau menyekutukan Allah SWT. Sehingga tradisi selikuran yang diperingati oleh masyarakat Desa Tirto dan sekitarnya pada saat memperingati wafatnya Sunan Geseng dan dilakukan satu tahun sekali yaitu pada malam ke-21 bulan Ramadhan tersebut diganti dengan tradisi ziarah makam dan pengajian. Masyarakat berdatangan untuk berziarah dan mendengarkan pengajian dan ceramah 
yang disampaikan oleh seorang kyai yang sengaja diundang oleh panitia untuk memberikan ceramah.

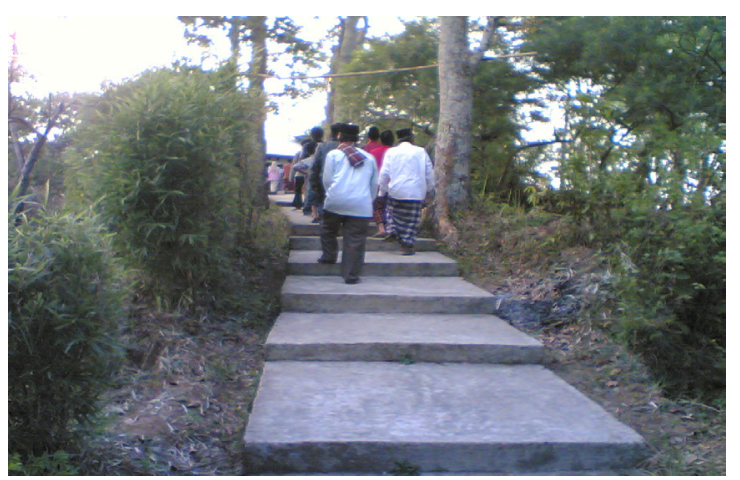

Gambar 5. Jalan Menuju makam Sunan Geseng.

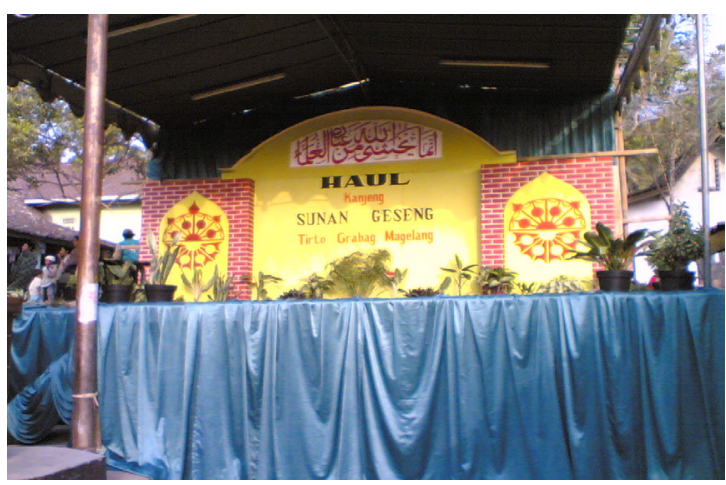

Gambar 6. Tempat pengajian Haul memperingati wafatnya Sunan Geseng

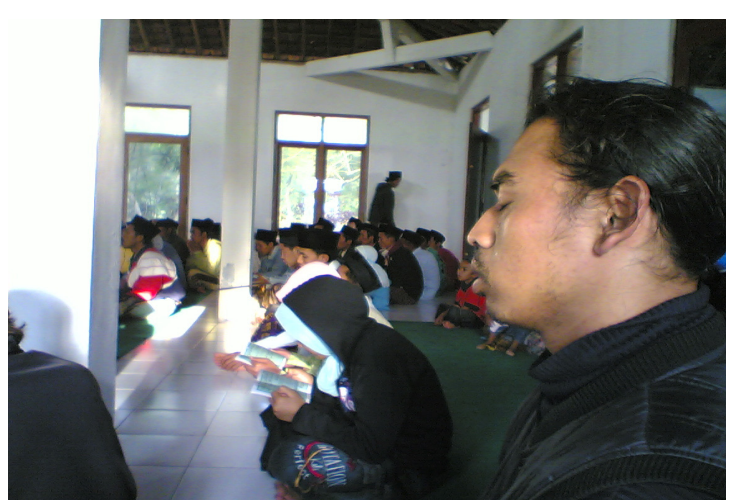

Gambar 7. Para peziarah yang berdo'a membaca Yasin dan Tahlil

Tradisi gendurenan yang dilaksanakan pada hari-hari tertentu yaitu pada saat 7 hari (mitung dino), 40 hari (matang puluh), 100 hari (nyatus), 1 tahun (mendak sepesan atau lebih dikenal dengan tradisi haul), 1000 hari (nyewu) memperingati kematian seseorang adalah tradisi slametan yang dilakukan oleh ke- luarga si mayat untuk mendo'akan arwah si mayat. Dalam gendurenan keluarga si mayat akan mengundang kerabat dan tetangga untuk mendoakan si mayat dengan membaca tahlil bersama. Keluarga orang yang meninggal harus menyiapkan berkat yang diletakkan dalam besek atau bakul plastik dan berisi nasi, sayur, lauk pauk, serta makanan ringan (snack) yang berupa apem dan ketan. Kedua makanan tersebut diartikan sebagai lambang permohonan kepada Allah SWT terhadap kesalahan-kesalahan si mayat.

Aktifitas-aktifitas keagamaan masyarakat yang berhubungan dengan slametan yaitu antara lain: Upacara Kelahiran, Aqiqoh (berkurban), Upacara pernikahan, Upacara kematian. Selain kegiatan keagamaan masyarakat yang berhubungan dengan tradisi slametan, masyarakat sekitar komplek makam Sunan Geseng juga melaksanakan berbagai aktivitas keagamaan lainnya. Perilaku keagamaan pada masyarakat di wilayah komplek makam Sunan Geseng dapat dilihat dari dua bentuk ibadah yang mereka jalankan seharihari. Ibadah ini bersifat rutinitas sehingga bersifat kesinambungan dan secara teori harus dilaksanakan secara konsisten. Ibadah tersebut adalah sholat lima waktu, berpuasa dibulan ramadhan, mengeluarkan zakat dan beramal dalam bentuk harta benda seperti zakat mal dan shodaqoh. Selain ibadah tersebut perilaku keagamaan masyarakat juga dapat dilihat dalam muamalahnya. Muamalah ini tercermin dalam konsep ukhuwah islamiyah seperti tolong-menolong, saling bertegur sapa, dan berkumpul bersama baik dalam acara pengajian-pengajian maupun acara slametan.

Ajaran muamalah itu terlihat pada berbagai bentuk kegiatan yang diselenggarakan oleh masyarakat yaitu yang bertujuan untuk mempererat silaturahmi antara warga masyarakat, antara lain yaitu: pengajian ibu-ibu yang dilaksanakan pada setiap malam Rabu, pengajian remaja putri yang dilaksanakan pada setiap malam Jum'at, dan pengajian bapak-bapak yang dilaksanakan setiap malam Jum'at juga. Selain itu setiap ada anggota masyarakat yang mengalami musibah atau anggota keluarganya meninggal maka ibu-ibu dan remaja putri pada $b a^{\prime} d a$ magrib 
dan bapak-bapak pada $b a^{\prime} d a$ isya berkumpul bersama dan mengadakan tahlilan sampai hari ke-7 (mitung dino) selesai.

Pada acara gendurenan yang terdahulu menggunakan makanan apem dan ketan yang diibaratkan sebagai permintaan ampun semua dosa-dosa orang yang meninggal, sekarang lebih sering menggunakan bahan makanan mentah atau sembako saja yaitu terdiri dari: beras seperempat kilogram, gula seperempat kilogram, telur ayam 2 butir, dan mie instant 2 bungkus. Meskipun masih banyak masyarakat yang menggunkan apem dan ketan tetapi ada juga masyarakat yang menggunakan sembako.

Begitu pula dengan slametan yang disebut juga dengan gendurenan yang dilakukan oleh masyarakat di sekitar komplek makam Sunan Geseng merupakan upacara keagamaan yang paling umum. Menurut Clifford Geertz (1981: 13) slametan melambangkan kesatuan mistis dan sosial mereka yang ikut didalamnya. Handai taulan, tetangga, rekan sekerja, sanak keluarga, arwah setempat, nenek moyang yang sudah mati, dan dewadewa yang sudah terlupakan, semuanya duduk bersama dalam satu meja dan karena itu terkait ke dalam suatu kelompok sosial tertentu yang mewajibkan tolong menolong dan bekerjasama. Slametan merupakan wadah bersama masyarakat, perorangan, dengan suatu cara yang memperkecil ketidakpastian, ketegangan dan konflik. Demikian juga acara slametan atau yang disebut genduren pada masyarakat di sekitar komplek makam Sunan Geseng yang dapat mempererat tali silaturahmi antara anggota masyarakat. Slametan yang dilakukan oleh masyarakat di komplek makam Sunan Geseng sendiri adalah kegiatan slametan yang berhubungan dengan kegiatan-kegiatan keagamaan khusus yang terjadi pada masyarakat. Acara slametan dilakukan sebelum dilaksanakannya acara khusus, dan dilanjutkan dengan acara gendurenan yang memakai berbagai makanan khusus seperti ketan dan apem yang mempunyai arti tersendiri, kemudian disertai pembacaan yasin dan tahlil.

Sedangkan fungsi agama yang lain adalah fungsi transformatif yang mengubah bentuk kehidupan masyarakat lama kedalam bentuk yang baru. Dalam fungsi transformatif ini nilai-nilai lama diganti dengan menanamkan nilai-nilai baru, serta membentuk nilai-nilai adat yang diwariskan dari generasi sebelumnya, yaitu yang berupa pola-pola pikir, pola-pola kelakuan, yang kesemuanya itu harus ditaati oleh anggota masyarakat. Dalam hal ini dapat dicontohkan bahwa masyarakat di wilayah Grabag yang dahulu masih mempercayai hal-hal gaib dan masih dipengaruhi oleh ajaran Hindhu-Budha, dengan datangnya Sunan Geseng ke wilayah Grabag untuk menyebarkan dan berda'wah di wilayah tersebut, maka masyarakat mulai mentransformasi nilai-nilai lama yang bersifat musrik atau menyekutukan Allah SWT dengan nilai-nilai baru dan diwujudkan dalam kegiatan keagamaan yang lebih Islami. Hal tersebut dapat terlihat dalam berbagai bentuk kagiatan keagamaan yang masyarakat lakukan sekarang ini.

Masyarakat di wilayah komplek makam Sunan Geseng yang menjalankan ajaran Ahlussunah wal jama'ah, dapat diartikan sebagai suatu proses dari masyarakat dalam menjalankan nilai-nilai keagamaan dari ajaran yang mereka yakini guna mencapai kebutuhan dasar yang berkenaan dengan dunia supra empiris, dimana mereka memiliki pola-pola perilaku yang relatif tetap dalam menjalankannya sesuai dengan ajaran agamanya. Kehidupan keagamaan masyarakat di sekitar komplek makam Sunan Geseng itu sendiri terlihat pada pola perilaku masyarakat dalam usahanya untuk menerapkan nilai-nilai agama yang masyarakat yakini kedalam kehidupan sehari-hari. Hal tersebut tercermin dalam aktifitas keagamaan masyarakat serta bagaimana ajaran-ajaran Sunan Geseng yang diyakini oleh masyarakat dapat merujuk masuk kehidupan masyarakat di wilayah tersebut.

Menurut Robertson (1992:7) bahwa pengkajian yang dilakukan bersama-sama memiliki dampak yang positif bagi para anggota yang terlibat didalamnya yaitu tiadanya kesimpangsiuran keyakinan di dalam diri masyarakat terhadap ajaran-ajaran yang masyarakat kaji. Pendapat ini terbukti pada masyarakat di wilayah komplek makam Sunan Geseng, masyarakat semakin meyakini 
dan mempercayai kebenaran dari apa yang difirmankan oleh Allah SWT. Penebalan keyakinan dan kepercayaan ini diistilahkan dengan kata taqwa. Hal ini dapat dilihat dari berbagai pandapat para anggota yang sebagian besar mengatakan bahwa dengan mengikuti ajaran para wali yang merupakan penerus Rasul Allah, masyarakat mengalami perubahan tingkah laku dan semakin bertaqwa terhadap Allah SWT hingga masyarakat merasa keyakinannya meningkat.

\section{SIMPULAN}

Ajaran Sunan Geseng yang masih dilaksanakan oleh masyarakat di wilayah komplek makam sampai saat ini dikerenakan oleh karisma Sunan Geseng. Dalam melaksanakan syiar Islam Sunan Geseng menggunakan cara dakwah ataupun pendekatan yang sederhana kepada rakyat kecil dengan cara penyampaian yang sederhana sesuai dengan kemampuan akal yang diajak berbicara, dan yang lebih penting Sunan Geseng memberi contoh dengan perbuatanperbuatan yang baik. Sehingga cukup banyak juga yang terpengaruh dan mengamalkan ajaran-ajaran Sunan Geseng tersebut dalam kehidupan sehari-hari. Dalam kegiatan-kegiatan keagamaan yang dilakukan oleh masyarakat di sekitar komplek makam Sunan Geseng adalah tradisi gendurenan, methoan, slametan, dan tradisi-tradisi yang lainnya se- perti tradisi selikuran yang dilakukan di makam sunan Geseng, mewujudkan kerukunan hidup dalam masyarakat. Masyarakat juga menganggap peninggalan-peninggalan Sunan Geseng tersebut sebagai objek dari sentimen kemasyarakatan.

\section{DAFTAR PUSTAKA}

Aziz, A.A., dkk. 2004. Kekeramatan Makam (Studi Kepercayaan Masyarakat terhadap Kekeramatan Makam-makam Kuno di Lombok). Jurnal Penelitian Keislaman. 1(1): 59-77

Arroisi, A. 2000. Wali Sanga. Bandung: PT. Remaja Rosdakarya

Bodan dan Tylor dalam Moleong, Lexy. 2002. Metodologi Penelitian Kualitatif. Bandung: Remaja Rosdakarya

Budiyanto, M., dkk. 2008. Pergulatan Agama dan Budaya; Pola Hubungan Islam dan Budaya Lokal di Masyarakat Tutup Ngisor, Lereng Merapi, Magelang. Jurnal Penelitian Agama. 17(3)

Danandjaja, J. 1986. Foklor Indonesia Imu Gosip, Dongeng, dan Lain-lain. Jakarta: PT. Pustaka Grafitipers

Fitri, A.Z. 2008. Pola Interaksi Harmonis antara Mitos, Sakral dan Kearifan Lokal Masyarakat Pasuruan. Jurnal el Harakah. 14(1)

Geertz, C. 1981. Abangan, Santri, Priyayi Dalam Masyarakat Jawa. PT Dunia Pustaka Jaya

Rahgiyanti. 2011. Fungsi Sungai Bagi Masyarakat di Tepian Sungai Kuin Banjarmasin. Jurnal Komunitas. 3(1): 51-56

Robertson, R. 1992. Agama: Dalam Analisa dan Interpretasi Sosiologi. Jakarta: Rajawali Pers

Sartini. 2004. Menggali Kearifan Lokal Nusantara Sebuah Kajian Filsafati. Jurnal Filsafat. 37(2) 